applications. Its competence was subsequently expanded to include aeronautical and land mobile communications. Privatization, which was completed in April 1999, transferred the business to a newly created company and the Organization remains as a regulator to ensure that the company fulfils its public services obligations. The company has taken the Inmarsat name and the Organization uses the acronym IMSO. In Jan. 2006 the Organization had 88 member parties.

Organization. The Assembly of all Parties to the Convention meets every two years.

Headquarters: 99 City Road, London EC1Y 1AX, UK.

IMSO Website: http://www.imso.org

e-mail:info@imso.org

Immarsat Website: http://www.inmarsat.com

Director of the Secretariat, IMSO: Jerzy Vonau.

Chief Executive, Inmarsat Ltd: Andrew Sukawaty.

\section{International Olympic Committee (IOC)}

Founded in 1894 by French educator Baron Pierre de Coubertin, the International Olympic Committee is an international nongovernmental, non-profit organization whose members act as the IOC's representatives in their respective countries, not as delegates of their countries within the IOC. The Committee's main responsibility is to supervise the organization of the summer and winter Olympic Games. It owns all rights to the Olympic symbols, flag, motto, anthem and Olympic Games.

Aims. 'To contribute to building a peaceful and better world by educating youth through sport, practised without discrimination of any kind and in the Olympic Spirit, which requires mutual understanding with a spirit of friendship, solidarity and fair play.'

Finances. The IOC receives no public funding. Its only source of funding is from private sectors, with the substantial part of these revenues coming from television broadcasters and sponsors.

Address: Château de Vidy, Case Postale 356, CH-1007

Lausanne, Switzerland.

Website: http://www.olympic.org

President: Jacques Rogge (Belgium).

\section{International Organization for Migration (IOM)}

Established in Brussels in 1951 to help solve European population and refugee problems through migration, and to stimulate the creation of new economic opportunities in countries lacking certain manpower. IOM is committed to the principle that humane and orderly migration benefits migrants and society.

Members (116 as of Dec. 2005). Afghanistan, Albania, Algeria, Angola, Argentina, Armenia, Australia, Austria, Azerbaijan, Bahamas, Bangladesh, Belarus, Belgium, Belize, Benin, Bolivia, Bosnia-Herzegovina, Brazil, Bulgaria, Burkina Faso, Cambodia, Cameroon, Canada, Cape Verde, Chile, Colombia, Congo (Democratic Republic of), Congo (Republic of), Costa Rica, Côte d'Ivoire, Croatia, Cyprus, Czech Republic, Denmark, Dominican Republic, Ecuador, Egypt, El Salvador, Estonia, Finland, France, Gabon, Gambia, Georgia, Germany, Greece, Guatemala, Guinea, Guinea-Bissau, Haiti, Holy See, Honduras, Hungary, Iran, Ireland, Israel, Italy, Jamaica, Japan, Jordan, Kazakhstan, Kenya,
South Korea, Kyrgyzstan, Latvia, Liberia, Libya, Lithuania, Luxembourg, Madagascar, Mali, Malta, Mauritania, Mexico, Moldova, Morocco, Netherlands, New Zealand, Nicaragua, Niger, Nigeria, Norway, Pakistan, Panama, Paraguay, Peru, Philippines, Poland, Portugal, Romania, Rwanda, Senegal, Serbia and Montenegro, Sierra Leone, Slovakia, Slovenia, South Africa, Sri Lanka, Sudan, Sweden, Switzerland, Tajikistan, United Republic of Tanzania, Thailand, Togo, Tunisia, Turkey, Uganda, Ukraine, UK, USA, Uruguay, Venezuela, Yemen, Zambia and Zimbabwe. 24 governments and a large number of government agencies and NGOs have observer status.

Activities. As an intergovernmental body, IOM acts with its partners in the international community to: assist in meeting the operational challenges of migration; advance understanding of migration issues; encourage social and economic development through migration; work towards effective respect of human dignity and the well-being of migrants. Since 1952 the IOM has assisted some $11 \mathrm{~m}$. refugees and migrants to settle in over 125 countries. Throughout 2001 the organization assisted in the humanitarian emergency unfolding in Afghanistan by way of shelter programmes and the registration of IDPs (internally displaced persons), and by meeting the needs of the displaced brought on by drought and conflict. In 2001 IOM launched a 'Migration and Development in Africa Programme' and a 'Migration Policy and Research Programme'. IOM's operational budget in 2004 was US\$641m.

Official languages: English, French, Spanish.

Headquarters: Route des Morillons 17, РOB 71, 1211

Geneva 19, Switzerland.

Website: http://www.iom.int

Director-General: Brunson McKinley (USA).

\section{International Organization for Standardization (ISO)}

Established in 1947, the International Organization for Standardization is a non-governmental federation of national standards bodies from some 145 countries worldwide, one from each country. ISO's work results in international agreements which are published as International Standards. The first ISO standard was published in 1951 with the title 'Standard reference temperature for industrial length measurement'.

Some 15,400 ISO International Standards are available on subjects in such diverse fields as information technology, textiles, packaging, distribution of goods, energy production and utilization, building, banking and financial services. ISO standardization activities include the widely recognized ISO 9000 family of quality management system and standards and the ISO 14000 series of environmental management system standards. Standardization programmes are now being developed in completely new fields, such as food safety, security, social responsibility and the service sector.

Mission. To promote the development of standardization and related activities in the world with a view to facilitating the international exchange of goods and services, and to developing co-operation in the spheres of intellectual, scientific, technological and economic activity.

Headquarters: 1 rue de Varembé, Case postale 56, CH-1211

Geneva 20, Switzerland.

Website: http://www.iso.org

e-mail: central@iso.org

Secretary-General: Alan Bryden. 